\title{
Law Enforcement Issues and Regulations in Undelimited Maritime Boundaries: An International Law Perspective
}

\author{
Esther Christie Erlina \\ Universitas Padjadjaran, Indonesia \\ christierlina0308@gmail.com \\ Raden Ahmad Gusman Catur Siswandi
Universitas Padjadjaran, Indonesia
ahmad.gusman@unpad.ac.id
}

ABSTRACT

Maritime boundaries play an essential role in determining the state's sovereignty, rights to exploit natural resources, maintain security, and territorial integrity. However, maritime boundaries often overlap between states, which can amount to conflicts. Maritime areas whose boundaries have not been agreed between neighboring states are referred to as "undelimited maritime boundaries" (UMB). Indeed, Article 74 of the United Nations Convention on the Law of the Sea 1982 has set out rules regarding UMB. However, conflicts still arise between states; for instance, the conflict related to law enforcement between Indonesia and Viet Nam in the South China Sea. This study aims to analyze law enforcement issues and the rights and obligations of states in UMB under international law. This study uses normative legal research which applies the method of legislative, conceptual, and analytical approaches. This study finds that states involved in UMB are prohibited from carrying out excessive law enforcement since it could trigger more conflicts and will hamper the ongoing final maritime delimitation negotiation process. In order to ensure zero conflicts during the negotiation process, this paper recommends that Indonesia should make every effort to enter into a comprehensive provisional arrangement about UMB with its neighboring states.

KEYWORDS: International Law, Law Enforcement, Undelimited Maritime Boundaries.

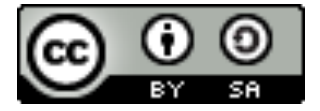

Copyright $\odot 2020$ by Author(s)

This work is licensed under a Creative Commons Attribution-ShareAlike 4.0 International License. All writings published in this journal are personal views of the authors and do not represent the views of this journal and the author's affiliated institutions.

\section{HOW TO CITE:}

Erlina, Esther Christie \& Raden Ahmad Gusman Catur Siswandi. "Law Enforcement Issues and Regulations in Undelimited Maritime Boundaries: An International Law Perspective" (2020) 7:1 Lentera Hukum 1-16.

Submitted: February 02, 2020 Revised: February 15, 2020 Accepted: February 18, 2020 


\section{INTRODUCTION}

Undelimited Maritime Boundaries (UMB) are areas where the continental shelf or exclusive economic zone (EEZ) of neighboring states overlap, or may potentially overlap, and there have not been any boundaries agreement established either through multilateral or bilateral agreements or court decisions. ${ }^{1}$ United Nations Convention on the Law of the Sea 1982 (UNCLOS 1982) has been regarded as the most critical convention regulating various matters regarding the law of the sea. Though UNCLOS 1982 has provided regulations concerning the law of the sea, the amount of conflicts at sea is still significantly high. ${ }^{2}$ One of the most complicated issues at sea are issues regarding $\mathrm{UMB}$, where states are usually faced with conflicts relating to the enforcement of their rights, obligations, and jurisdiction. ${ }^{3}$ States tend to exercise their rights, obligations, and jurisdiction in the form of law enforcement in maritime areas, which are still undelimited. ${ }^{4}$ The act of law enforcement in UMB conducted by one state often violated the municipal law of another state, which consequently arises conflict that may jeopardize the ongoing maritime boundary negotiation between them. ${ }^{5}$

Article 74(1) of UNCLOS 1982 stated that the delimitation of EEZ between states with opposite or adjacent coasts should be effected by agreement based on international law in order to achieve an equitable solution. Subsequently, Article 74(3) of UNCLOS 1982 stipulated that if the states concerned still have a pending agreement, the states, in a spirit of understanding and cooperation, shall make every effort to enter into provisional arrangements of a practical nature, and not jeopardize or hamper the reaching of the final agreement during the transitional period. In short, Article 74 of UNCLOS 1982 has established several obligations for states within UMB, inter alia: (a) the delimitation of the EEZ between states shall be effected by agreement based on international law in order to achieve an equitable solution (paragraph 1 ) ${ }^{6}$ (b) states shall make every effort to enter into provisional arrangement of a practical nature (paragraph 3); ${ }^{7}$ and (c) states shall not jeopardize or hamper the reaching of the final agreement (paragraph 3). ${ }^{8}$ Based on the abovementioned regulations, states who conduct any excessive law enforcement can violate Article 74(3).

1 British Institute of International and Comparative Law (BIICL), Obligations of States in Undelimited Maritime Areas (London, published online on BIICL's website at http://www.biicl.org/undelimitedmaritime-area, 2016) at 11.

2 Elisio Beneditio Jamine, Maritime Boundaries Delimitation, Management and Dispute Resolution (United Nations, New York, 2007) at 2.

3 R. R Churchill \& A. V. Lowe, The Law of the Sea (Manchester University Press, Manchester, 1999) at 181 .

4 Nugzar Dundua, Delimitation of Maritime Boundaries between Adjacent States (United Nations, New York, 2007) at 3.

5 Adiwerti Sarahayu Lestari, Implikasi Perjanjian Tentang Penetapan Garis Batas Laut Teritorial Antara Indonesia dan Singapura di Selat Singapura (Bachelor Thesis of Universitas Indonesia, Depok, 2007) at 15.

6 Article 74(3), UNCLOS 1982.

7 Ibid.

8 Ibid. 
Indonesia is an archipelagic state that borders with ten countries, and some of them are still undelimited, for instance, with Viet Nam in the EEZ. A recent incident between Indonesia and Viet Nam occurred in the North Natuna Sea on April 27, 2019. It started when Indonesian Coast Guard KRI Tjiptadi 381 captured Vietnamese Fishing Vessel BD 979, conducting illegal fishing within their UMB. When KRI Tjiptadi 381 tried to board and inspect BD 979, the Vietnamese Coast Guard, KN 264, and KN 213, purposely rammed KRI Tjiptadi 381 in order to protect BD 979. Responding to this incident, Indonesia stated that the law enforcement KRI Tjiptadi 381 conducted was under the procedure laid out under Indonesian law. However, Viet Nam claimed that the area where BD 979 conducted the fishing activity was within the jurisdiction of Viet Nam. Consequently, a conflict between Indonesia and Viet Nam arose out of overlapping claims. ${ }^{9}$

This study aims to analyze the rights, obligations, and jurisdiction of every state to law enforcement actions in UMB, specifically in the EEZ. This study focuses on two issues. First, to what extent does states with UMB can carry out law enforcement activities? Second, what are the limitations Indonesia must consider in settling disputes arising out of law enforcement activities within the UMB? Subsequently, this article will be divided into three parts. The first part will discuss issues between Indonesia and Viet Nam relating to law enforcement in UMB. The second part will analyze how Article 74 of UNCLOS 1982 regulates about the rights and obligations of states in UMB along with its state practice. Lastly, the third part will elaborate on the limitations Indonesia must consider in settling disputes arising out of law enforcement activities in UMB by creating a comprehensive provisional arrangement concerning maritime boundaries.

\section{LAW ENFORCEMENT ISSUES IN UNDELIMITED MARITIME BOUNDARIES BETWEEN INDONESIA AND VIET NAM}

Indonesia and Viet Nam have UMB in several areas concerning the EEZ segment, such as in the South China Sea and North Natuna Sea.

\section{A. South China Sea}

With the continental shelf zone, Indonesia and Viet Nam have agreed on several maritime boundaries through an Agreement between Indonesian and Viet Nam's Government concerning Establishment of Continental Shelf Boundaries which have been signed-in Hanoi, on 26 June 2003 and ratified through Law Number 182007 concerning Establishment Continental Shelf, 2003. ${ }^{10}$

9 Directorate General of Law and International Treaties of the Ministry of Foreign Affairs of the Republic of Indonesia, Pertemuan Teknis ke-12 Batas Maritim RI-Vietnam, Awali Konsultasi Informal Provisional Arrangement, August 22, 2019, accessed through https://kemlu.go.id/portal/id/read/543/ berita/ri-vietnam-mulai-perundingan-zee-natuna-utara, dated January 2, 2020, 5.14 pm.

10 Law No. 18 Year 2007 concerning the Agreement between the Indonesian Government and the Vietnamese Government concerning the Establishment of Continental Shelf Zone, 2003. 
In regards to the EEZ, based on the research uploaded in Seminar Nasional Badan Informasi Geospasial's (BIG) official website, ${ }^{11}$ Indonesia and Viet Nam went through a negotiation process regarding their EEZ boundaries in the South China Sea in 2010. From 2010 until 2016, there have been eight rounds of the negotiation process. The $8^{\text {th }}$ negotiation was held on March 22-24, 2016, in Bali. The technical team of each state discussed "Draft Consolidated Text of The Proposed Principles and Guidelines," however, this negotiation still leaves one pending paragraph related to the legal basis of EEZ boundaries along with delimitation. ${ }^{12}$

Until the latest round of negotiation, the main discussion of Indonesia and Viet Nam still revolves around the delimitation area and potential boundaries line on each states' EEZ. Presently, Viet Nam still unilaterally claim EEZ rights within the South China Sea using the single maritime boundary principle by referring to the continental shelf agreement concluded with Indonesia, while Indonesia still adhere to UNCLOS 1982, believing that the double maritime boundary principle must be used in establishing maritime boundaries with Viet Nam. According to Article 1 of Agreement between The Government of the Socialist Republic of Viet Nam and The Government of The Republic of Indonesia Concerning the Delimitation of the Continental Shelf Boundary, ${ }^{13}$ the boundary between the Vietnamese and the Indonesian continental shelves is defined by the straight lines connecting the following points specified by coordinates and in the sequence given below:

\begin{tabular}{|l|c|c|c|}
\hline No. & Point & Latitude & Longitude \\
\hline 1. & 20 & $06^{\circ}$ & $\begin{array}{c}05^{\prime} 48^{\prime \prime} 105^{\circ} \\
49^{\prime} 12^{\prime \prime} \mathrm{E}\end{array}$ \\
\hline 2. & H & $06^{\circ}$ & $15 f 00^{\prime \prime} \mathrm{N} 106^{\circ} 12^{\prime} 00^{\prime \prime} \mathrm{E}$ \\
\hline 3. & HI & $06^{\circ}$ & $15 f 00^{\prime \prime} \mathrm{N} 106^{\circ} 19^{\prime} 0 l^{\prime \prime} \mathrm{E}$ \\
\hline 4. & A4 & $06^{\circ}$ & $20^{\prime} 59.88^{\prime \prime} \mathrm{N} 106^{\circ} 39 \mathrm{f} 37.67^{\prime \prime} \mathrm{E}$ \\
\hline 5. & XI & $06^{\circ}$ & $50^{\prime} 15^{\prime \prime} \mathrm{N} 109^{\circ} 17^{\prime} 13^{\prime \prime} \mathrm{E}$ \\
\hline
\end{tabular}

The single maritime boundary principle which Viet Nam carries allows states to consider that the continental shelf area and its EEZ are deemed as a unity. Thus the

Il Tri Patmasari, Eko Artanto, and Astrit Rimayanti, Perkembangan Terakhir Batas Maritim Indonesia dengan Negara Tetangga, (Article presentation in the Seminar Nasional Geospasial Dalam Membingkai NKRI, 2016), at 13.

12 Callistasia Wijaya, Konflik Indonesia-Vietnam "Terancam Terus Berulang” Selama Belum Ada Kesepakatan Zona Ekonomi Eksklusif, May 1, 2019, accessed through https://www.bbc.com/indonesia/indonesia-48103607, dated January 2, 2020, $4.55 \mathrm{pm}$.

13 Article 1, Agreement between The Government of The Socialist Republic of Viet Nam and The Government of The Republic of Indonesia Concerning the Delimitation of The Continental Shelf Boundary, 2003. 
EEZ is equated with the area of its continental shelf. ${ }^{14}$ Based on the table mentioned above, it is acknowledged that the provided coordinates of continental shelf area incorporates the disputed EEZ area between Indonesia and Viet Nam. While Viet Nam argues the single maritime boundary principle, Indonesia stands with the double maritime boundary principle, which rules that the continental shelf and the EEZ are two separate entities. Therefore, the two states have not yet come into an agreement concerning their EEZ claims. Until today, a provisional arrangement between Indonesia and Viet Nam regarding their disputed EEZ in the South China Sea is still on finalization. ${ }^{15}$

\section{B. North Natuna Sea}

Indonesia and Viet Nam have overlapping ZEE claims within the North Natuna Sea. As mentioned in the previous subsection, the UMB between Indonesia and Viet Nam in the North Natuna Sea was a result of the Continental Shelf Boundaries Agreement in 2003. Viet Nam's stance was that their EEZ boundaries must be considered the same as their continental shelf boundaries in the North Natuna Sea. However, Indonesia believes that the continental shelf and EEZ are two different regimes, as explicitly stated in UNCLOS 1982. Therefore, the overlapping area has become the core problem for both states.

One of the issues between Indonesia and Viet Nam within the North Natuna Sea happened in April 2019 where Indonesian Coast Guard KRI Tjiptadi 381 arrested Vietnamese Fishing Vessel BD 979, which conducted illegal fishing within their UMB as a form of law enforcement. At that time, KRI Tjiptadi 381 was conducting law enforcement operation in the North Natuna Sea, and the Vietnamese Coast Guard, KN 264, and KN 213 was guiding Vietnamese Fishing Vessel BD 979 conduct fishing in that area. The Indonesian Government considered the Vietnamese Fishing Vessel to be fishing illegally, and after trying to communicate with the vessel but received no response, KRI Tjiptadi 381 acted on the Vietnamese Fishing Vessel by pulling and bringing it to the nearest port. Consequently, KN 264 and KN 213 blocked and dashed KRI Tjiptadi 381, which caused the collision and the sinking of BD 979. ${ }^{16}$ Responding to this incident, the Commander in Chief of the Indonesian Navy Admiral Rear, Yudo Margono, delivered a press statement stating that the capture towards Vietnamese Fishing Vessel was under the procedures of Indonesian law. However, Vietnam claimed that the waters are a part of Viet Nam's EEZ as well.

Presently, Indonesia and Viet Nam have conducted 12 rounds of technical meetings. The latest technical meeting was held in Surabaya on August 20-21, 2019. In the latest technical meeting, Indonesia and Viet Nam have agreed to start constructing a provisional arrangement regarding the overlapping area di North Natuna Sea as an

14 BIICL, supra note 1 at 8.

15 Interview with Hudiansyah Is Nursal, S.H., MILIR., Head of Sub-Directorate of International Law and Legislation, January 15, 2020.

16 Ibid. 
effort to avoid another harmful incident between the two states by strengthening communication, implementing mutual restraint, and restrictions of fishing activities. ${ }^{17}$

\section{UNDELIMITED MARITIME BOUNDARIES REGULATIONS UNDER INTERNATIONAL LAW}

Generally, there are no restrictions for states to conduct unilateral claims within their $\mathrm{UMB}$ with another state. Under Anglo-Norwegian Fisheries Case (United Kingdom v Norwegia) ${ }_{1}^{18}$ essentially it is every states' right to conduct unilateral claims; however, when it comes to maritime delimitation, the states concerned must negotiate following what is stipulated under international law. Unilateral claims can be implemented in various forms, one of which is by conducting law enforcement activities. ${ }^{19}$ In conducting law enforcement activities as a form of a unilateral claim, states must take into account the limitations provided under international law.

\section{A. UNCLOS 1982}

Article 74 of UNCLOS 1982 has set out rules for states with UMB, specifically in their EEZ. This article lays out four paragraphs, as follows:

1. The EEZ delimitation of the EEZ between states with opposite or adjacent coasts shall be effected by agreement based on international law in order to achieve an equitable solution;

2. If no agreement can be reached within a reasonable period, states concerned shall resort to the procedures provided within Part XV of UNCLOS 1982;

3. Pending agreement as provided for in paragraph 1 , the states concerned, in a spirit of understanding and cooperation, shall make every effort to enter into provisional arrangements of a practical nature and, during the transitional period, not to jeopardize or hamper the reaching of the final agreement;

4. Where there is an agreement in force between the states concerned, any questions relating to the delimitation of the EEZ shall be determined in accordance with the provisions of that agreement.

Pursuant to Article 74 of UNCLOS 1982, there are several general principles that must be implemented in conducting law enforcement within the UMB.

\section{Mutual cooperation and understanding principle}

This principle is elaborated in Article 74(3) of UNCLOS 1982, which provides that states shall make every effort to reach the final agreement in the spirit of understanding and cooperation. The phrasing "in a spirit of understanding and cooperation" is a general principle in negotiating that must be implemented, where the negotiating

\footnotetext{
17 R. R Churchill \& A. V. Lowe, supra note 3.

${ }^{18}$ Anglo-Norwegian Fisheries Case (U.K. v. Nor.), 1951 I.C.J. 117.

${ }^{19}$ Anglo-Norwegian Fisheries Case (U.K. v. Nor.), Judgement, 1951 I.C.J. 117, at 20.
} 
states must avoid every action which does not demonstrate the willingness to cooperate and understand.

\section{Mutual restraint principle}

Several articles in the 1928 General Act for the Pacific Settlement of International Disputes have further elaborated the implementation of the mutual restraint principle, where the negotiating states, as a form of restraint, have to avoid all actions which can jeopardize or harm the condition of the states concerned during the ongoing negotiation process. The example of restraint is drilling activity in the seabed and arrestment of vessels. ${ }^{20}$

\section{Good faith principle}

The phrasing Article 74(3) of UNCLOS 1982 used to vest states the obligation to act in good faith is "not to jeopardize or hamper the reaching of the final agreement," which means that states shall not conduct any harmful actions during effort to reach the final agreement negotiation period. In Heathrow Airport User Charges, ${ }^{21}$ it is stipulated that the implementation of the good faith principle in negotiating is where states make every effort to reach a final agreement. The phrase used in this case is, "Each of the states concerned... to use its best efforts to achieve particular goals."

Further, in the case of Guyana $v$ Suriname ${ }^{22}$ and Cameroon $v$ Nigeria, ${ }^{23}$ although the states should negotiate in good faith, the states concerned are not obliged to successfully reach the final agreement or create a provisional arrangement, as long as the states concerned have used its best efforts in good faith to negotiate. ${ }^{24}$ The principle of good faith itself is very much connected with the mutual restraint principle since the implementation of the good faith principle is the action of mutual restraint by the concerned states. If the concerned state conducts any actions which can harm, jeopardize or violate the current situation by not being able to perform the act of restraint, then the state can be deemed as acting in bad faith.

\section{No harm principle}

The International Court of Justice (ICJ) $)^{25}$ has established that, under customary international law, states are obliged to ensure that every activity conducted under the jurisdiction of the concerned state is in favor of the environmental condition of the other states. ${ }^{26}$ This rule does not only apply to the areas where there is a clear division

20 BIICL, supra note 1 at 19.

21 Arbitration concerning Heathrow Airport Use Charges (USA v United Kingdom) (1992) XXIC RIAA 1 .

22 Guyana v Suriname, Award, ICGJ 370 (PCA 2007), 17 th September 2007, Permanent Court of Arbitration [PCA].

23 Cameroon v Nigeria, [1998] ICJ Rep 275.

24 O. Ishmael, The Trail of Diplomacy: A Documentary History of the Guyana Venezuela Border Issue (Xlibris, United States, 2013) at 34.

25 Advisory Opinion on the Legality on the Use by a State of Nuclear Weapons in Armed Conflict, [1996] ICJ Rep 226, para. 29.

26 Pulp Mills on the River Uruguay (Argentina v Uruguay) [2010] ICJ Rep 14, para. 101. 
of sovereign rights between states but also to undelimited maritime areas. ${ }^{27}$ This rule implies that every state shall apply the principle of prevention and caution in carrying out all forms of activities in their UMB. Prevention here means that states have to prevent everything that may harm, endanger, or threaten the security of other states. ${ }^{28}$

\section{B. Rights of States in the UMB Based on Article 74 of UNCLOS 1982}

Mostly, there are no clear regulations under international law regarding states' rights in UMB unless there has been a provisional arrangement as provided in Article 74(3) of UNCLOS 1982 between the states concerned. Article 74(3) of UNCLOS 1982 explicitly pour out a phrase "without prejudice to the final delimitation," which amount to a legal consequence. The intended legal consequence is further elaborated by Lagoni, who stated that the arrangement being drafted, and every activity is carried out during the process of drafting the agreement unless the states agreed otherwise, give states certain rights to the concerned UMB and the resources within it. ${ }^{29}$

In matters where the states concerned have drafted a provisional arrangement, every final maritime delimitation negotiation must always be in line with the existing provisional arrangement, thus not violating the provisional arrangement. ${ }^{30}$ Therefore, it can be said that the exercise of states' rights within their UMB depends on the agreement concluded by the states concerned.

\section{Obligation of States and State Practices based on Article 74 of UNCLOS 1982}

As elaborated previously, Article 74 of UNCLOS 1982 stated that EEZ boundaries between states with opposite or adjacent coasts must be established through an agreement under international law. The question is to what extent does the concerned states can carry law enforcement activities in their EEZ where the boundaries have not been delimited?

Generally, there are no restrictions in international law related to law enforcement in UMB. However, this fact does not necessarily mean that law enforcement can be carried without implementing the limitations established in international law. The limitations here refers to the obligations of states under Article 74 of UNCLOS 1982 and the general principles of international law. As the general principles have been elaborated in subsection A of this chapter, states have the practice to establish several forms of provisional arrangements as provided in Article 74(3) of UNCLOS 1982, which are as follows:

\section{Barbados-Guyana EEZ Co-operation Treaty 2003}

This provisional arrangement regulates the establishment of a co-operation zone that consequently vests both Barbados and Guyana the right to exercise jurisdiction,

27 BIICL, supra note 1 at 20.

28 Ibid.

29 R. Lagoni, Interim Measures Pending Maritime Delimitation Agreements (78 AJIL 357, 1984) at 382.

30 Ibid. 
supervision, development, exploration, and exploitation of biological and nonbiological resources. ${ }^{31}$ The parties to this provisional arrangement have agreed to establish the co-operation zone, not to neglect or hinder the finalization of the final agreement of the maritime boundaries between them, and not to violate the general principles of international law and UNCLOS 1982.32

One of the highlights is that this provisional arrangement regulates specifically about co-operation in terms of law enforcement, which are as follows:

Article 7: Jurisdiction over Security Matters

I. The parties acting in good faith shall establish the procedures for the conduct of activities to police the co-operation zone;

II. Within three months of the date on which this Treaty enters into force, the Parties shall act in good faith commence the negotiation of a security agreement concerning activities to be undertaken within the co-operation zone, which may address among others:

a. Enforcement of regulations over natural resources;

b. Terrorism;

c. Prevention of illicit narcotics trafficking;

d. Trafficking in firearms, ammunition, explosives and other related materials;

e. Smuggling;

f. Piracy;

g. Trafficking in persons; and

h. Maritime policing and search and rescue.

III. Until a security agreement, as contemplated in paragraph 2, is in force. Unless otherwise provided for in this Treaty, each Party shall unilaterally exercise defense and criminal jurisdiction within and with the co-operation zone to the same extent that it may do so within and to that part of its EEZ that lies outside the cooperation zone.

\section{Joint Fishing Zone in East Asia}

One of the most complicated UMB is located within the East Asia area, specifically in the Yellow Sea, East China Sea, and Sea of Japan, where the UMB involves three states: Japan, South Korea, and China. These three states have agreed to conclude these agreements: ${ }^{33}$

I. Agreement between China and Japan as of November 111997 concerning the East China Sea (entered into force in 2000);

31 Article 1(1), Exclusive Economic Zone Co-Operation Treaty between the Republic of Guyana and the State of Barbados Concerning the Exercise of Jurisdiction in their Exclusive Economic Zones in the Area of Bilateral Overlap within Each of their Outer Limits and Beyond the Outer Limits of the Exclusive Economic Zones of Other States, 2003.

32 Article 1(2), ibid.

33 Rosenberg, Managing the Resources of the China Seas: China's Bilateral Fisheries Agreements with Japan, South Korea, and Vietnam, Japan Focus, Japan, 2005, Vol. 3 Issue 6, at 1-4; Y. Van Logchem, The Scope for Unilateralism in Disputed Maritime Areas in C. Schofield, S. Lee and M-S Kwon (eds), The Limits of Maritime Jurisdiction, Martinus Nijhoff, Dordrecht, 2014, at 179-181. 
II. Agreement between Japan and South Korea as of January 2000 concerning the East China Sea and Japan Sea; and

III. Agreement between China and South Korea as of 1998 concerning the Yellow Sea (entered into force in 2001).

These agreements primarily regulates three main points, which are: ${ }^{34}$

I. The affirmation of exclusive rights which every state owns towards the fisheries resources and fishing activities in each EEZs;

II. General principles concerning fisheries access which carries the principle of mutual benefit;

III. The regulation concerning a co-operation regime for fisheries resources which are divided equally.

3. 2012 Memorandum of Understanding (MoU) between Indonesia and Malaysia

Generally, this instrument does not regulate specifically regarding provisional arrangement, as provided in Article 74(3) UNCLOS 1982. This MoU set out rules regarding "Common Guidelines Concerning the Treatment of Fishermen by Maritime Law Enforcement Agencies of Malaysia and the Republic of Indonesia."

This agreement aims to establish guidelines for activities that both states will carry within their UMB related to fisheries issues, especially for the treatment of fishers. ${ }^{35}$ This MoU affirms that every activity carried out of the implementation of the MoU shall not neglect and harm the existing maritime delimitation agreements and the ongoing bilateral negotiations. ${ }^{36}$ On the other hand, this MoU also affirms that this MoU applies to every existing UMB between Indonesia and Malaysia. ${ }^{37}$

\section{RECOMMENDATIONS IN CREATING PROVISIONAL ARRANGEMENT}

The application of UNCLOS 1982 has led to the expansion of the authority of coastal states in enforcing their laws and regulations, especially outside the territorial sea area. The compromise that needs to be implemented between the application of the sovereignty of the coastal states and the application of the freedom of other states to sail and utilize sea areas following the principles of freedom of the high seas is reflected in several provisions of the UNCLOS 1982, particularly in Chapter V regarding EEZ. Thus, the regulation regarding EEZ concerns a special legal regime (sui generis), ${ }^{38}$ so that the law enforcement mechanism in this region can only be carried out by the

34 Rosenberg, ibid.

35 Article 1, Memorandum of Understanding Between the Government of the Republic of Indonesia and the Government of Malaysia in Respect of the Common Guidelines Concerning Treatment of Fishermen by Maritime Law Enforcement Agencies of the Republic of Indonesia and Malaysia, 2012.

36 Article 2(c), ibid.

37 Article 5, ibid.

38 Albert W. Koers, Konvensi Perserikatan Bangsa-Bangsa tentang Hukum Laut (Gajah Mada University Press, Yogyakarta, 1994) at 5. 
authorities of the coastal states, so long as it does not amount to any conflict that violates the provisions of international law, especially those incorporated in UNCLOS $1982 .{ }^{39}$

In addition, the enactment of UNCLOS 1982 resulted in the development of unilateral claims by coastal states, especially in terms of the EEZ and continental shelf region. This measure resulted in overlapping claims between various states all over the world. Generally, Article 74 and 83 of UNCLOS 1982 stipulates that maritime boundaries within the EEZ and continental shelf region between states with opposite or adjacent coasts must be established through an agreement under international law. While this type of final delimitation agreement has not been established, states must make every effort to enter into provisional arrangements, which are practical in nature and concrete, as provided in Article 74(3) of UNCLOS 1982.

Moreover, Article 74(3) stipulates that various principles must be taken into account by states in situations where their boundaries in the EEZ have not been determined, namely the principle of cooperation and understanding, mutual restraint, and no harm. With regards to law enforcement activities within the UMB concerning the EEZ region, states must pay attention to the general principles of international law, especially the ones related to the threat or use of force. ${ }^{40}$ In this case, states must avoid the use of force as far as possible (unavoidability), and if it is unavoidable, the threat or use of such violence must be appropriately conducted (reasonableness) and only insofar as necessary (necessity). ${ }^{41}$

With regards to the activity of law enforcement within EEZ regimes, which boundaries have not been delimited, the Indonesian Government must identify every possibility of various types of provisional arrangements that can be implemented by Indonesia and its neighboring states, which is practical. An excellent provisional arrangement must at least comprise as follows: (a) the affirmation of sovereign rights and limited jurisdiction which can be carried out by each state; (b) the establishment of provisional lines or shared zones that are still awaiting final finalization; (c) law enforcement mechanisms, including code of conduct and ROE which can be carried out by authorities from the concerned states; (d) joint management of natural resources mechanism within the EEZ regime, such as joint fisheries zones; and (e) the affirmation of the fact that the establishment of a provisional arrangement must not harm, hinder, or jeopardize the efforts of the states concerned in setting their final maritime boundaries.

One important issue relating to the urgency of a conclusion of provisional arrangement within the Indonesian sea area is in the North Natuna Sea. North Natuna Sea is located in the northern part of the Natuna islands as included administratively within the Natuna Regency, Riau Islands Province. The existence of the North Natuna Sea was started from the naming a revamp of the Indonesian Territory map for asserting

39 J. G. Starke, An Introduction to International Law (Fifth Edition, Butterworths, London, 1963) at 172.

40 Swati Parashar, Maritime Counter-Terrorism: A Pan-Asian Perspective (Delhi, Dorling Kindersley, 2008) at 58.

41 Article 2(4), United Nations, Charter of the United Nations, 24 October 1945, I UNTS XVI. 
maritime zone boundaries in the North Natuna region which intersects with the South China Sea whose existence was briefly opposed by China, as a result of a joint boundary mapping activity between Indonesia and its neighboring states, such as Malaysia, Singapore, Philippines, and Viet Nam.

The North Natuna Sea, which is located on the border of several states in Southeast Asia, has become a fishery zone with incredible potentials. It resulted in North Natuna Sea as a "hot spot" for foreign fishing vessels to conduct their illegal exploitation of fishes. Thus, to overcome the problems that exist in the North Natuna Sea, the states concerned may consider making a provisional arrangement regarding their boundaries, similar to what South Korea and China made in 2000. ${ }^{42}$ The KoreaChina Fisheries Agreement 2000 is a bilateral agreement between South Korea and China, which divides the Yellow Sea into two zones. The first zone is a transition zone, which becomes the EEZ for each state, and the second zone is a temporary zone, which is a joint-fishing ground between South Korea and China. The situation in the Yellow Sea between South Korea and China is very likely to be applied in the North Natuna Sea, where Indonesia and Viet Nam, or its other neighboring states, can establish joint fishing zones and a committee of representatives from each state to determine vessel permits, total fishing catches, and supervision rights.

\section{CONCLUSION}

This study aims to analyze issues arising out of the implementation of Article 74 of UNCLOS 1982, precisely issues relating to law enforcement activities. Under UNCLOS 1982, there are no specific articles that regulate matters relating to violations of law within the UMB. Article 74(3) of UNCLOS 1982 only stated that states who are facing issues within their UMB are obliged to make every effort to enter into a provisional arrangement regarding their UMB in order to avoid conflict and maintain international security and peace. The provisional arrangement, as provided in UNCLOS 1982, is aimed to be in favor of the ongoing maritime delimitation negotiation process to avoid the concerned states from harmful conflicts.

As the current practice shows, provisional arrangements have been partly implemented by Indonesia, where Indonesia and Malaysia have agreed to implement specific treatment for fishers in UMB. One of the provisions agreed by both states are that if there happen to be illegal fishing activities conducted by each states' fishermen, the authorities of either Indonesia or Malaysia will only be allowed to conduct law enforcement in the form of warning and not using any form of excessive law enforcement unless the fishing vessel captured uses fishing gears that could harm and jeopardize the marine environment.

Mostly, the enforcement of the national law of one state in UMB is not prohibited under international law. However, the exercise of law enforcement must actively take

42 Xue, G. (2004). China's response to international fisheries law and policy: national action and regional cooperation. 
into account the conditions, peace, and international security of the sea. It is reaffirmed through the Anglo-Nonwegian Fisheries Case, which stated that it is every state's right to exercise unilateral claims within their $\mathrm{UMB}$, however, when it comes to maritime delimitation, the states concerned must negotiate according to what is stipulated under international law. The unilateral claim referred previously includes the exercise of law enforcement activities.

In order to avoid overlapping law enforcement in the UMB, the states concerned must adhere to what is regulated under UNCLOS 1982, one of which is to enter into a comprehensive provisional arrangement. The states involved in UMB are prohibited from carrying out excessive law enforcement since it could trigger more conflicts and will hamper the ongoing final maritime delimitation negotiation process. Furthermore, the states concerned should focus more on the rules regarding law enforcement through a precise provisional arrangement to avoid excessive conflicts. A proportionate law enforcement should be taken into account, since this kind of law enforcement will not cause too much tension between the concerned states.

It is essential for Indonesia to immediately finalize the current maritime delimitation with its neighboring states, particularly with Malaysia and Viet Nam. In order to ensure zero conflicts during the negotiation process, this paper recommends that Indonesia should make every effort to enter into a comprehensive provisional arrangement concerning UMB with its neighboring states. About Viet Nam, Indonesia can refer to the provisional arrangement made by Barbados and Guyana through the adoption of the EEZ Co-operation Treaty. Provisional arrangements that are clear, comprehensive, and firm, must be concluded so that Indonesia can no longer experience conflicts that would disrupt diplomatic relations between Indonesia and its maritime neighbors.

\section{ACKNOWLEDGMENTS}

None.

\section{COMPETING INTERESTS}

The authors declare that they have no competing interests.

\section{REFERENCES}

Albert W. Koers, Konvensi Perserikatan Bangsa-Bangsa tentang Hukum Laut (Gajah Mada University Press, Yogyakarta, 1994).

J. G. Starke, An Introduction to International Law (Fifth Edition, Butterworths, London, 1963).

R. R Churchill \& A. V. Lowe, The Law of the Sea (Manchester University Press, Manchester, 1999). 
Xue, G. (2004). China's response to international fisheries law and policy: national action and regional cooperation.

Swati Parashar, Maritime Counter-Terrorism: A Pan-Asian Perspective (Delhi, Dorling Kindersley, 2008).

O. Ishmael, The Trail of Diplomacy: A Documentary History of the Guyana Venezuela Border Issue (Xlibris, United States, 2013).

Y. Van Logchem, The Scope for Unilateralism in Disputed Maritime Areas in C. Schofield, S. Lee and M-S Kwon (eds), The Limits of Maritime Jurisdiction, Martinus Nijhoff, Dordrecht, 2014.

British Institute of International and Comparative Law ("BIICL"), Obligations of States in Undelimited Maritime Areas (London, published online on BIICL's website at http:/www.biicl.org/undelimited-maritime-area, 2016).

Elisio Beneditio Jamine, Maritime Boundaries Delimitation, Management and Dispute Resolution (United Nations, New York, 2007).

Nugzar Dundua, Delimitation of Maritime Boundaries between Adjacent States (United Nations, New York, 2007).

Tri Patmasari, Eko Artanto, and Astrit Rimayanti, Perkembangan Terakhir Batas Maritim Indonesia dengan Negara Tetangga, (Article presentation in the Seminar Nasional Geospasial Dalam Membingkai NKRI, 2016).

Adiwerti Sarahayu Lestari, Implikasi Perjanjian Tentang Penetapan Garis Batas Laut Teritorial Antara Indonesia dan Singapura di Selat Singapura (Bachelor Thesis of Universitas Indonesia, Depok, 2007)

R. Lagoni, Interim Measures Pending Maritime Delimitation Agreements (78 AJIL 357, 1984).

Rosenberg, Managing the Resources of the China Seas: China's Bilateral Fisheries Agreements with Japan, South Korea, and Vietnam, Japan Focus, Japan, 2005, Vol. 3 Issue 6.

United Nations, Charter of the United Nations, 24 October 1945, I UNTS XVI.

UN General Assembly, Convention on the Law of the Sea, 10 December 1982, available at: https://www.refworld.org/docid/3dd8fdlb4.html [accessed l February 2020].

Agreement between The Government of The Socialist Republic of Viet Nam and The Government of The Republic of Indonesia Concerning the Delimitation of The Continental Shelf Boundary, 2003.

Law No. 18 Year 2007 concerning the Agreement between the Indonesian Government and the Vietnamese Government concerning the Establishment of Continental Shelf Zone, 2003.

Memorandum of Understanding Between the Government of the Republic of Indonesia and the Government of Malaysia in Respect of the Common Guidelines Concerning Treatment of Fishermen by Maritime Law Enforcement Agencies of the Republic of Indonesia and Malaysia, 2012.

Exclusive Economic Zone Co-Operation Treaty between the Republic of Guyana and the State of Barbados Concerning the Exercise of Jurisdiction in their Exclusive Economic Zones in the Area of Bilateral Overlap within Each of their Outer 
Limits and Beyond the Outer Limits of the Exclusive Economic Zones of Other States, 2003.

Anglo-Norwegian Fisheries Case (U.K. v. Nor.), 1951 I.C.J. 117.

Anglo-Norwegian Fisheries Case (U.K. v. Nor.), Judgement, 1951 I.C.J. 117, at 20.

Arbitration concerning Heathrow Airport Use Charges (USA v United Kingdom) (1992) XXIC RIAA 1.

Guyana v Suriname, Award, ICGJ 370 (PCA 2007), 17th September 2007, Permanent Court of Arbitration [PCA].

Cameroon v Nigeria, [1998] ICJ Rep 275.

Advisory Opinion on the Legality on the Use by a State of Nuclear Weapons in Armed Conflict, [1996] ICJ Rep 226.

Pulp Mills on the River Uruguay (Argentina v Uruguay) [2010] ICJ Rep 14.

Directorate General of Law and International Treaties of the Ministry of Foreign Affairs of the Republic of Indonesia, Pertemuan Teknis ke-12 Batas Maritim RI-Vietnam, Awali Konsultasi Informal Provisional Arrangement, August 22 2019, accessed through https://kemlu.go.id/portal/id/read/543/berita/ri-vietnam-mulai-perundingan-zeenatuna-utara, dated January 2, 2020, 5.14 pm.

Callistasia Wijaya, Konflik Indonesia-Vietnam "Terancam Terus Berulang” Selama Belum Ada Kesepakatan Zona Ekonomi Eksklusif, May 1 2019, accessed through https:/www.bbc.com/indonesia/indonesia-48103607, dated January 2 2020, $16.55 \mathrm{pm}$.

Interview with Hudiansyah Is Nursal, S.H., MILIR., Head of Sub-Directorate of International Law and Legislation, January 15, 2020. 
16 | Law Enforcement Issues and Regulations in Undelimited Maritime Boundaries: An International Law Perspective

This page is intentionally left blank 